\title{
International mobility of students - Its impact on labour market forecasts and its contribution to the Dutch economy
}

Citation for published version (APA):

Fouarge, D., \& Özer, M. N. (2014). International mobility of students - Its impact on labour market forecasts and its contribution to the Dutch economy. ROA. ROA Technical Reports No. 006 https://doi.org/10.26481/umarot.2014006

Document status and date:

Published: 01/01/2014

DOI:

10.26481/umarot.2014006

Document Version:

Publisher's PDF, also known as Version of record

\section{Please check the document version of this publication:}

- A submitted manuscript is the version of the article upon submission and before peer-review. There can be important differences between the submitted version and the official published version of record. People interested in the research are advised to contact the author for the final version of the publication, or visit the DOI to the publisher's website.

- The final author version and the galley proof are versions of the publication after peer review.

- The final published version features the final layout of the paper including the volume, issue and page numbers.

Link to publication

\footnotetext{
General rights rights.

- You may freely distribute the URL identifying the publication in the public portal. please follow below link for the End User Agreement:

www.umlib.nl/taverne-license

Take down policy

If you believe that this document breaches copyright please contact us at:

repository@maastrichtuniversity.nl

providing details and we will investigate your claim.
}

Copyright and moral rights for the publications made accessible in the public portal are retained by the authors and/or other copyright owners and it is a condition of accessing publications that users recognise and abide by the legal requirements associated with these

- Users may download and print one copy of any publication from the public portal for the purpose of private study or research.

- You may not further distribute the material or use it for any profit-making activity or commercial gain

If the publication is distributed under the terms of Article $25 \mathrm{fa}$ of the Dutch Copyright Act, indicated by the "Taverne" license above, 


\section{International mobility of students}

Its impact on labour market forecasts and its contribution to the Dutch economy

Didier Fouarge Merve Özer

\section{ROA Technical Report}

ROA-TR-2014/6

Researchcentrum voor Onderwijs en Arbeidsmarkt | ROA Research Centre for Education and the Labour Market | ROA 


\section{International mobility of students}

Its impact on labour market forecasts and its contribution to the Dutch economy

Didier Fouarge

Merve Özer

ROA-TR-2014/6

December 2014

Research Centre for Education and the Labour Market

Maastricht University

P.O. Box 616, 6200 MD Maastricht, The Netherlands

$\mathrm{T}+31433883647 \mathrm{~F}+31433884914$

secretary-roa-sbe@maastrichtuniversity.nl

www.roa.nl 


\section{Table of Contents}

Table of Contents

1 Introduction 2

2 Labour market impacts of international students: A literature review 5

2.1 Types of study migration 5

2.2 Benefits of degree mobility in terms of labour market: A review on $\begin{array}{ll}\text { retention of degree-mobile students } & 7\end{array}$

2.3 Potential costs of degree mobility in terms of labour market 10

3 Student mobility in the Netherlands $\quad 12$

3.1 Incoming student mobility 12

$\begin{array}{ll}3.2 \text { Outgoing student mobility } & 19\end{array}$

3.3 Net study migration 23

4 Sensitivity of labour markets forecasts to study migration 24

4.1 Inflow of graduates and degree migration 24

4.2 Sensitivity of forecasts 26

5 Conclusion $\quad 30$

$\begin{array}{ll}\text { References } & 31\end{array}$

Appendix: Further dimensions of study mobility $\quad 35$

A.1 Costs of student mobility 36

$\begin{array}{lll}\text { A.2 Benefits of student mobility } & 37\end{array}$ 


\section{Introduction}

International student mobility has rapidly increased in the past three decades: the number of students enrolled in tertiary education outside of their country of citizenship was 0.8 million in 1975, but it increased to 4.3 million in 2011 (OECD, 2013). ${ }^{1}$ This rapid increase can be explained by several factors: internationalization and standardization of higher education (e.g., the Bologna process in European Union countries), global increase in demand for tertiary education, faster information flows thanks to the advancements in communication and transportation opportunities, and policies to encourage student exchange through bilateral agreements (Tremblay, 2005; OECD, 2013; Van Bouwel \& Veugelers, 2013). For students, there are several benefits to engaging in higher education abroad. International study mobility is an opportunity to achieve education in fields that are unavailable in the home country or are known to be of better quality in another country, to increase their future employment opportunities and earnings, or to improve their language and intercultural skills (Fouarge and van Thor, 2011; Varghese, 2008). While study mobility is an investment decision made by students for their own self-development and future career opportunities, it has important implications in terms of sending and receiving countries in a broader context of human capital accumulation of a country. From the sending countries' perspective, student mobility might be used as a means of transferring new knowledge and technology to their countries if migrant students return back to their home countries or establish networks with their country of origin (Tremblay, 2005; Gribble, 2008). Also the host countries might benefit from student mobility because of expanded available resources for their higher education institutions, enhanced productivity of the labour market inflow of student due to positive selection in study migration, improved international reputation of their higher education systems, or because those students can be employed in the host country after graduation, and student mobility can be positioned in a broader strategy of attracting high skilled expatriates (Tremblay, 2005; Centraal Planbureau, 2012; Abella, 2006).

As industrialized economies in the context of globalization have been evolving towards knowledge-based economies, having a sufficiently large stock of skilled manpower has become a key concern to keep pace with competitors. This has important implications in terms of brain migration considering skill shortages faced by those countries especially in the context of an aging population. Being aware of this fact, many OECD countries have put several measures into effect in order to relax their migration regulations in favour of sustaining temporary or permanent stay of high skilled migrants since the late 1990s (see Tremblay, 2005; Abella, 2006; Kahanec \& Zimmermann, 2011). Student mobility is an important complement of these efforts considering the large and increasing pool of foreign students in several OECD countries, of which some are currently pursuing active policies to attract high

\footnotetext{
${ }^{1}$ This report was written as part of the Project Onderwijs-Arbeidsmarkt (POA) of ROA. We thank the members of the POA advisory board, especially Djoerd de Graaf, for the useful comments provided on an earlier draft.
} 
skilled migrants (OECD, 2013). Considering that migration is a selective process (Aslanbeigui \& Montecinos, 1998; Grogger \& Hanson, 2013), incoming students provide the opportunity to the host countries to attract the best students among many good students as potential future high skilled migrants. This means that student mobility is of strategic importance as a policy for attracting highly skilled expatriates.

Although the flow of international students to developed OECD countries has been rising, a portion of those students prefer to return back to their home countries or to migrate to another country. This leads to discussions in the literature regarding the validity of concepts such as "brain drain", "brain gain", or "brain circulation" (see Straubhaar, 2000; Rizvi, 2005; Lee \& Kim, 2010; Gibson \& McKenzie, 2011). Even if the proportion of international students intending to stay in their host countries is initially high, actual stay rates might not coincide with those rates (Sykes \& Chaoimh, 2012). This is because the decision to stay, to return, or to migrate another country is affected by relative opportunities in labour markets of different economies as well as family, cultural, and political factors (Lee \& Kim, 2010; Bratsberg, 1995). In this respect, how and to what extent international students contribute to the national economy and labour market after their graduation are important questions from the perspective of host countries. Considering the labour market shortages and implementation of policies aiming to fill those shortages in OECD countries, the retention rate of international students after graduation and their incorporation in the labour market become key issues that determine the extent to which countries receiving large flows of international students are able to make use of this opportunity to attract them as highly-skilled immigrants.

The Netherlands is one of those countries that face an aging labour force and skill shortages in particular sectors. Therefore, the Netherlands is currently pursuing policies to ease migration procedures of high-skilled immigrants as well as to attract more international students. As a result of the Bologna process and the promotion activities in some non-EU countries, the number of international students has exhibited an increasing trend in recent years just like in other countries around the world (Becker \& Kolster, 2012). In addition, a new scheme came into force in 2007 according study migrants the right to stay for one more year in the Netherlands in order to search for a suitable job. The aim is that international graduates from Dutch bachelor's and master's programs obtain the highly-skilled migrant status (Sykes \& Chaoimh, 2012). So besides the efforts to attract international students, the Netherlands is increasing its efforts to keep those students in productive employment after graduation. In this regard, the retention rate of international students and their transition to productive employment is a key issue also for Dutch economy.

In this study, we first discuss the contribution of study migrants to the labour market. This contribution crucially depend on the retention rate of study migrants in the Dutch labour market. Then we investigate the impact study migration has on ROA's labour market forecasts by educational type. The number of international students staying in the Netherlands after graduation is crucial when making labour market forecasts for the inflow into the labour market: if foreign students completing their degree are counted as inflow - as is the case in the Referentieramingen (Ministerie van 
Onderwijs, Cultuur en Wetenschap, 2013) - and the retention rate is less than one, then one would overestimate the true labour supply. To assess the sensitivity of ROA's labour market forecasts, we take the inflows of international graduates to the Dutch labour market into account and estimate the impact of those inflows on the balance between supply and demand balance in the following six years by field of education.

The rest of the paper is organized as follows: Section 2 presents a literature review on the potential impacts of international graduates on labour market, with a specific focus on the retention of degree-mobile students in the Netherlands. Recent data and trend information on student mobility in the Netherlands is discussed in Section 3. In Section 4, the sensitivity of ROA's labour market forecasts by fields of education to the inclusion of foreign students who take their degree in the Netherlands is discussed. Section 5 concludes. 


\section{Labour market impacts of international students: A literature review}

\section{$2.1 \quad$ Types of study migration}

The labour market contribution of international mobile students crucially depend on the extent to which they stay in their host country upon graduation. Studies on retention rates of international students and proportion of foreign students intending to stay in the host country provide a variety of results that are difficult to compare and inconclusive to derive a clear measure of retention. This makes evaluating potential labour market contribution of international students difficult. One of the reasons is that the data sources used cover different groups of international students by type of mobility and/or level of study. Therefore, classifying internationally mobile students by the type of mobility (and also level of study) is important before discussing the potential contribution of student mobility to the host country's labour market. This is because intention of staying and actual retention might exhibit significant differences between certain groups of international students. In this report, international students are grouped under two broad categories: credit-mobile and degree-mobile students.

Credit-mobile students are mainly exchange students who are enrolled in higher education institutions and go abroad to study in a host institution for a limited period of time to earn credits under some bilateral agreements or exchange program schemes. The most well-known exchange program scheme is the Erasmus Program of the European Commission that provides the opportunity to students to go abroad for a period of 3 to 12 months at any stage of their study cycle. Credit-mobile students are mostly concentrated in bachelor's degree programs (European Commission, 2013). They enrol in programs or courses in host institutions for a limited period of time, receive a scholarship to cover their travel and subsistence costs, and are exempted from any kind of fees for their studies (European Commission, 2014).

The second group of international students is degree-mobile students who enrol in a full-time bachelor's and/or master's program of study with the aim to obtain a diploma at the end of their study. The literature sometimes also considers PhD students to be degree-mobile students. Although all of those students are longer-term migrants compared to the limited duration of credit-mobile students in the host country, PhD students differ from degree-mobile students in bachelor's and master's programs. While bachelor's and master's students are regular students who pay their tuition fees to enrol in study programs, PhD students are usually employed by their host institution and involved in productive activities in the form of research and teaching.

The degree of labour market contribution of study migration is expected to differ by groups of international students as mentioned above. First of all, credit-mobile students are not expected to participate in the labour market in the host country due to the following reasons. As mentioned earlier, most of the credit-mobile students are 
in bachelor's degree programs (European Commission, 2013), their duration of stay in the host country is usually short, and they eventually return back to their home countries since they are already enrolled in study programs in their home countries. However, it should be noted that students spending some of their study time abroad through exchange programs are more likely to migrate again after their graduation (de Grip et al., 2010; Parey \& Waldinger, 2011). So if credit-mobile students prefer to migrate to their earlier host countries after graduation (due to the familiarity they gain during their exchange visits), credit mobility might be a precursor of further degree or high-skilled labour mobility.

Secondly, although $\mathrm{PhD}$ students are sometimes considered as mobile students in the literature as mentioned above, they are actually high skilled migrants considering their participation in productive activities in the labour market for higher education. International $\mathrm{PhD}$ students coming to the Netherlands have been benefiting from regulations for skilled migrants since 2004 (Sykes \& Chaoimh, 2012) so they are a part of labour market just like skilled immigrant workers. Although the retention of $\mathrm{PhD}$ students after graduation is important for host countries being in need of skilled immigrants to fill labour market shortages, it could be analysed as a long-term stay decision of skilled migrants rather than retention of mobile students.

Lastly, degree-mobile bachelor's and master's students might participate into the host country's labour market while studying through internship programs as a part of their study program. However, it should be noted that those internship programs are not required in all study programs so many incoming students fall out of this category (Tremblay, 2005). Although non-EU students are allowed to work only for a limited number of hours per week if they have a separate work permit (Becker \& Kolster, 2012), EU students do not face such restriction. However, degree-mobile bachelor's and master's students are not expected to participate extensively into the labour market and do productive work since they mostly attend full-time education. This means that the potential contribution of degree-mobile students to the host country's labour market crucially depends on their retention after graduation.

In light of the above distinction in types of study mobility, this report concentrates on the labour market contribution of degree mobility, and particularly on the retention of international students in bachelor's and master's degree programs. In this respect, international bachelor's and master's students constitute a specific group in terms of ROA's labour market forecasts since this group's transition to the Dutch labour market has important implications for gains and losses of the Netherlands from student mobility as a host country. Also, the inflow of degree mobile students on the Dutch labour market could potentially affect the labour market prospects of nationals (see Section 4). 


\subsection{Labour market benefits of degree mobility: retention rates of degree- mobile students}

Student mobility might be a channel for attracting future high-skilled migrants to the labour market. ${ }^{2}$ Abella (2006) refers to this strategy as "academic-gate approach" in the sense that students who come to a host country for their study are highly qualified due to the selective nature of migration process and they can enter to the labour market at a relatively low cost. This might be due to the fact that obtaining a diploma from a university in the host country increases the chance that their skills be acknowledged by institutions offering post-graduate degrees and companies in the host country (Tremblay, 2005). Thus, student mobility might be also used by students as a means of entering into the labour market of a host country (Tremblay, 2005).

\section{International evidence on the retention of study migrants}

The US, as a country with a long immigration tradition, seems benefiting mostly from retention of international graduates. According to an earlier study conducted by U.S. Immigration and Naturalization Service in 2000, 23\% of current temporary work permission $(\mathrm{H}-1 \mathrm{~B})$ holders at that time was previously holding a student visa. Another survey conducted by Barucha et al. (2007) among master's students in US and UK universities also showed that only $30.5 \%$ of foreign students are planning to return to their home countries right after completing their study program, but that the intention to stay in the US is higher compared to that in UK. Retention of PhD graduates is also very high in the US: $68 \%$ of $\mathrm{PhD}$ earners in 2006 were still in the US in 2011 (Finn, 2014). 10-year stay rate calculated for the $2001 \mathrm{PhD}$ earners cohort is $65 \%$, but it differs by filed of study: the stay rate is highest among graduates from engineering fields (Finn, 2014). Finn (2014) showed that retention rate for temporary visa holders is similar to those figures and intention to stay is a good predictor of the actual retention rate among $\mathrm{PhD}$ graduates in the US.

Intentions of international students to stay in Western European countries seem also high, at least in the short term, but lower than in the US. A survey conducted in 2011 among non-EU master's and PhD students in five EU countries showed that most of the students have intentions to stay at least for 1-2 years after completing their studies mainly to gain international work experience (Sykes \& Chaoimh, 2012), which provides evidence that student mobility constitutes a path for entry into the labour market. According to the results of this survey, $35.2 \%$ and $20.1 \%$ of international master's and $\mathrm{PhD}$ students in the Netherlands are planning to stay for 1-2 and 3-5 years more, respectively. Only $6.1 \%$ of them are planning to stay more than 5 years (Sykes \& Chaoimh, 2012). Just like in the US, this study shows that students in technical fields are more inclined to stay (Sykes \& Chaoimh, 2012). This is to be expected considering skill shortages in technical sectors and the related promising labour market opportunities. However, to the best of our knowledge, there is lack of information regarding the actual stay rates of those post-graduate students in Europe

\footnotetext{
${ }^{2}$ In an appendix, we discuss other costs and benefits of student mobility for the host country.
} 
so that a comparison with intentions as well as with retention rate in the US is not possible.

Intentions of stay and actual retention rates might differ by destination country and country of origin as well as level an field of study. Data on several OECD countries reveal that short-term retention rates of degree-mobile students (at bachelor's and master's level) are below $35 \%$ as presented in Figure 2.1. This indicator provided by OECD (2011) was calculated as the proportion of international students changing their visa status from student visa to students who did not renew their visas in 2008 (or in 2009 for some countries). Although this indicator is not fully reliable because of inconsistencies between data sources, it provides an insight for short-term retention trends in several OECD countries (OECD, 2011). According to Figure 2.1, the retention rate in the Netherlands is above $25 \%$ which is the OECD average, and the Netherlands is one of the countries that achieves the highest rentention rate. In addition, it was estimated that $80 \%$ or more of those changes in visa status in the Netherlands are work-related (OECD, 2011), which suggests that the retention of foreign students benefits the Dutch labour market.

Figure 2.1: Percentage of foreign students changing visa status in 2008-2009

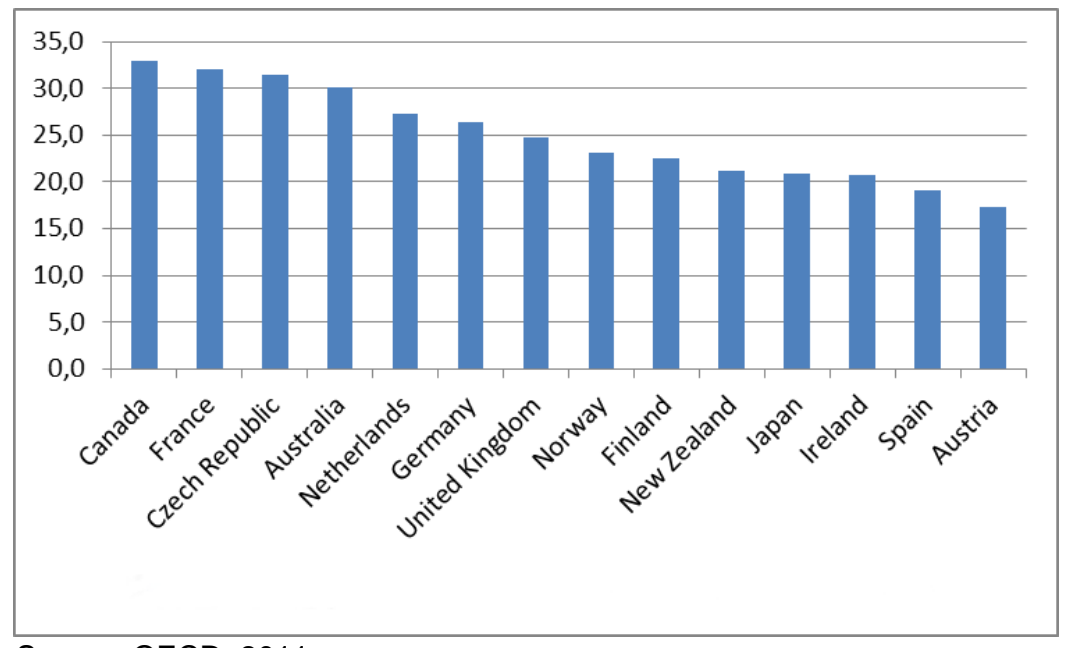

Source: OECD, 2011

Retention rates of study migrants in the Netherlands

Besides OECD's short-term retention rate based on simple accounting, there are several other studies addressing the stay rates of international students in the Netherlands. These studies make use of administrative records and/or survey data. One of those studies was conducted by Bijwaard (2010) by using register data for the Netherlands for the period 1995-2003. The author estimated that the average duration of the stay of a migrant student in the Netherlands after graduation is 29 months. $45 \%$ of study migrants left the Netherlands during the observation period while in the long term, only $19 \%$ of students permanently stay in the Netherlands. According to Dutch regulation, every person who enters to the country and stays at 
least 4 months should register with the local municipality. Thus, the register data used by Bijwaard (2010) cover all migrants who stay at least 4 months in the Netherlands, thereby including credit-mobile students (e.g., under the Erasmus scheme) who are supposed to stay in the Netherlands from 3 to 12 months. In this respect, expected short period of stay for credit-mobile students might cause a downward bias in the estimates of Bijwaard (2010). The estimated 19\% permanent retention rate might therefore be considered as a lower bound.

Other estimates available for incoming students in the Netherlands give much higher retention rates compared to that of Bijwaard (2010). A summary of the findings of those studies is presented in a Dutch report prepared by Centraal Planbureau (2012). According to the results of HBO and WO Monitor conducted in 2007-2011, the retention rate 1,5 years after graduation is $43 \%$ while micro data analysis conducted by CBS in 2010 shows that $38 \%$ and $34 \%$ of foreign graduates remained and were employed in the Netherlands after 3-4 and 13-15 years of graduation, respectively. Results from the UM-Scanner conducted among Maastricht University graduates in 2010 show that the retention rate of EU students is $22 \%$ and $29 \%$ in $5-7$ and 9-12 years after graduation, respectively. These rates might give an idea about the retention rates of degree-mobile students in the short-, medium-, and long-term but should be taken with caution since these calculations might suffer from selection bias (see Centraal Planbureau, 2012).

In brief, estimates on retention rate of degree-mobile international students in the Netherlands range from $19 \%$ to $43 \%$ which might be considered as lower and upper bounds for the retention rate. As mentioned earlier, 19\% rate of retention estimated by Bijwaard (2010) is based on the data covering credit-mobile students who are inclined to leave the host country after a limited period time so this might be a downward-biased estimate. However, the $43 \%$ rate of retention estimated from HBO and WO Monitor reflects the retention only 1,5 years after graduation. Since intention to stay and actual retention might be high in early years following graduation considering the Dutch regulation allowing international students to stay one more year after graduation, this rate might represent the potential maximum of retention in the Netherlands.

In Section 4, we take these retention rates into account to test the sensibility of ROA's labour market forecast to various assumptions concerning the retention of study migrants in the Dutch labour market. However, it should be noted that the estimates mentioned above do not provide the opportunity of accurately evaluate whether estimated retention of international students are sufficient to alleviate labour market shortages in the Dutch economy. This is because of issues related to coverage of sample and selectivity, and lack of detail concerning the retention by field of study. In this respect, estimating the level of retention by level and field of study, and by type of mobility through the use of a representative sample or administrative records in the Netherlands might be an important topic for future research to better evaluate the impacts of international students on the Dutch labour market. It is further unknown to what extent the retention of international students varies over the business cycle. This could also be subject of future research. 


\subsection{Potential labour market costs of degree mobility}

As discussed so far, attracting highly skilled migrants is perceived as a solution to alleviate the pressure of aging population on labour force and skill shortages in labour market in many OECD countries, and student mobility might be a supporting mechanism for these attempts if retention rates are high enough to fill labour market shortages. In this respect, it is argued in the previous section that the labour market might benefit from international student mobility depending on the level of retention of international students. Nevertheless, it could be claimed that retention of international students after graduation, and their transition to labour market might negatively affect the employment opportunities of native graduates. This could be considered as a cost associated with degree mobility in terms of host country's labour market. This view is supported by Borjas (2004) who argues that enrolment of foreign PhD students in the US causes a displacement of white native American males. However, there is no consensus in the literature in the sense that studies conducted so far on so-called displacement effects do not provide any definite evidence on the negative effects of immigrants on natives' labour market outcomes (see Kerr \& Kerr, 2011).

In the context of the Dutch labour market, skill shortages are especially expected in specific segments of the technical and health care sector (ROA, 2013). As mentioned earlier, a survey conducted among master's and $\mathrm{PhD}$ students in five EU countries reveal that students in technical fields are more inclined to stay (Sykes \& Chaoimh, 2012) apparently due to promising employment prospects in those sectors. In case of skill shortages a potential displacement of native graduates due to retention of international students seems unlikely as these graduates will fill the gap between the labour demand by firms and the labour supply of nationals.

Even if it is assumed that there is a displacement effect, it should be considered with caution because there are other potential positive impacts of international student mobility, for example in terms of employment creation in the host country. According to a NAFSA report (2013), one international student enrolled in a US college or university created 0.43 jobs in sectors such as higher education, accomodation, and telecommunication through his/her spendings in 2012/13. A similar study by Münch and Hoch (2013) for the Netherlands reveals that average expenditure of an international student for consumption and accommodation created 0.15 annual additional jobs in 2010/11 in the Netherlands. Münch and Hoch (2013) also estimated that 0.29 annual additional jobs can be created through consumption spending per international student entering into the Dutch labour market after graduation. In this regard, the impact of international student retention on the host country's labour market should be evaluated by the relative magnitudes of job created and job displacement of natives.

Another cost aspect of degree mobility is that associated with outgoing study migration. While incoming students might constitute a potential gain for their host countries' labour markets, outgoing students might be a loss in terms of their home countries' workforce. In this respect, the number of outgoing students relative to 
incoming students and their retention rate in their host countries (or their return rate to their home countries) become key issues for OECD countries experiencing labour market shortages. In the Netherlands, the number of incoming students outweighs the number of outgoing students (see Section 3). However, the case of outgoing degree-mobile students has been neglected in this study because of the lack of data on return rates. 


\section{Student mobility in the Netherlands}

Each year, the Netherlands is attracting more and more international students from both EU and non-EU countries (Becker \& Kolster, 2012). Although tuition fees are higher, especially for non-EU students, compared to some other European countries, the Netherlands has fully adopted the European bachelor's/master's degree structures following the Bologna process, and has many English-taught bachelor's and master's programs (Becker \& Kolster, 2012). In order to attract students from developing countries, Nuffic Neso offices in 10 countries such as Brazil, India, Vietnam and Thailand carry out promotion activities, and the Netherlands also tries to attract those non-EU students as high-skilled migrants by allowing them to stay one more year after their graduation to look for a job (Becker \& Kolster, 2012). As a result of these efforts, student mobility has increased in recent years. We document these trends in this section.

\subsection{Incoming student mobility}

Trends in degree mobility

As Figure 3.1 shows, the number of foreign students in the Netherlands has been increasing since 2005. The main source of this increase is the increasing number of degree-mobile students rather than exchange students coming for study or work placement under the Erasmus program. Almost $80 \%$ of all incoming students are degree mobile students who have come to the Netherlands with the aim of obtaining a diploma. 
Figure 3.1: Number of foreign students in the Netherlands in 2005-2013

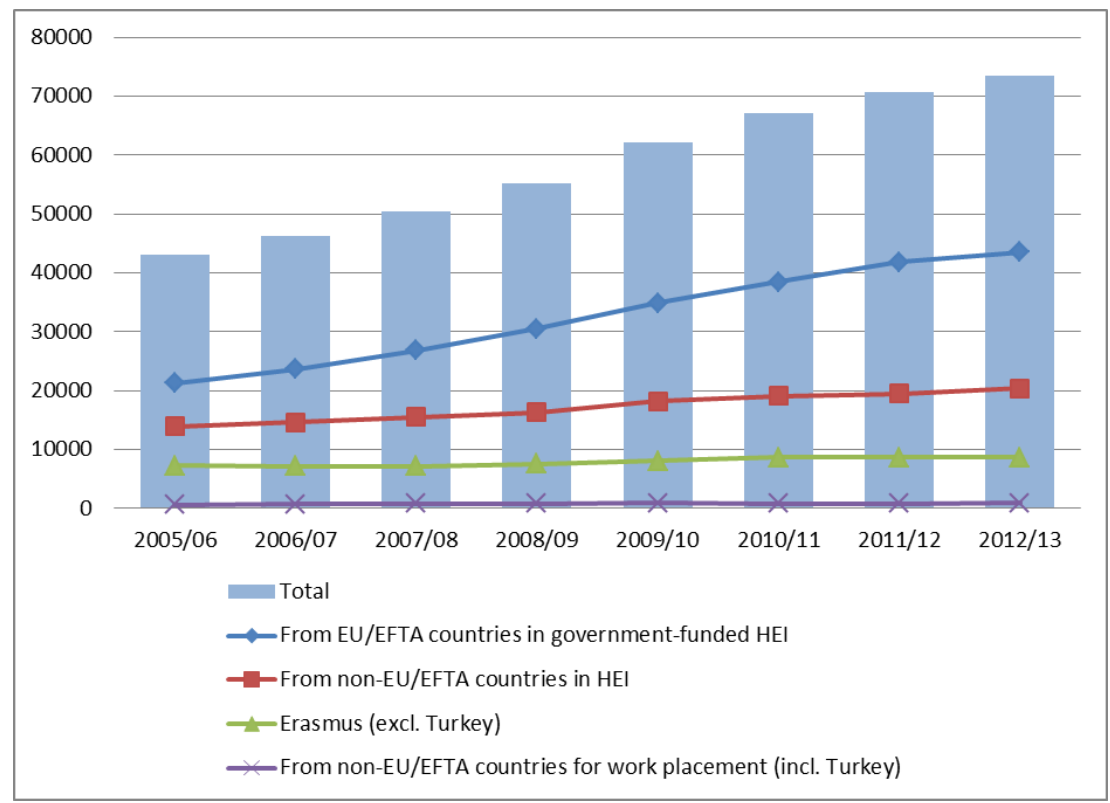

Source: Nuffic, 2014

The distribution of degree-mobile students over higher professional education (HBO - University of Applied Sciences) and academic higher education (WO - Research University) is given in Figure 3.2. In the academic year 2012/13, more than 58,000 foreign students were enrolled in higher education in the Netherlands and they were distributed almost equally between research universities and universities of applied sciences. The figure shows that the share of foreign students in total enrolment at research universities has always been higher than the share of foreign students in universities of applied sciences. From 2008 to 2013, the share of foreign students in total enrolment has increased from $6.2 \%$ to $6.9 \%$ in HBOs while it has increased from $8.6 \%$ to $12.2 \%$ in WOs. The share of foreign degree-mobile students in total enrolment in the Netherlands has increased from $7.1 \%$ to $8.8 \%$ in that period.

To put these percentages into perspective, according to UNESCO data, the share of international students in higher education in the US was about $3 \%$ in the 2000 s, while it increased from 10 to $15 \%$ in the UK between 2002 and 2009 (Choudaha and Chang, 2012). In Australia, this share ranged between 17 and 21\% in the 2000s. 
Figure 3.2: Number of degree-mobile foreign students and percentage share in total enrolment in the Netherlands by HBO and WO in 2008-2013

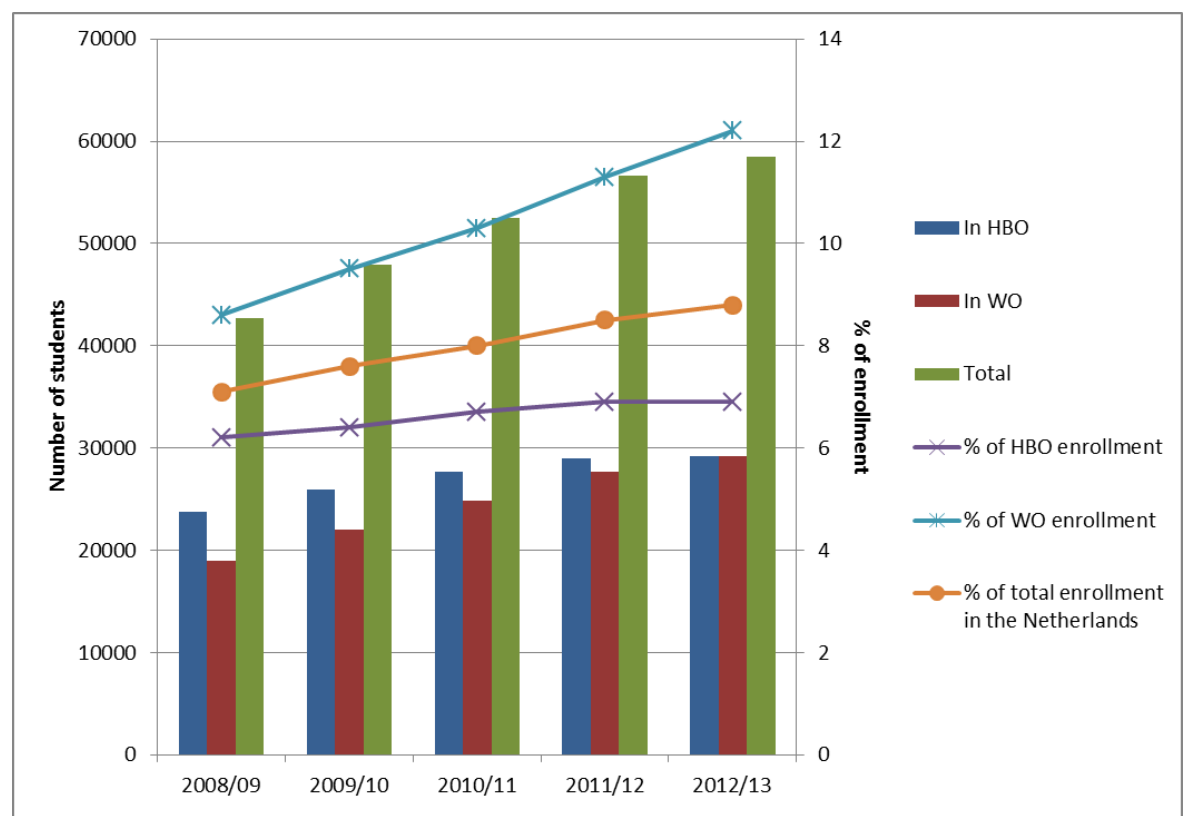

Source: Nuffic, 2014

At research universities (Figure 3.3), the number of degree mobile students in Bachelor's and the Master's programs is more or less similar. However, the increase in degree mobility between 2008 and 2013 in those universities has been higher in Master's programs (Figure 3.3). As Figure 3.4 shows, almost all (95\%) degree mobile students in universities of applied sciences in the Netherlands are engaged in Bachelor's programs, and their number has been increasing over the past few years. The number of degree mobile students in HBO master's programs, however, has hardly changed between 2008 and 2013. 
Figure 3.3: Number of degree-mobile foreign students in WOs by level of study in 2008-2013

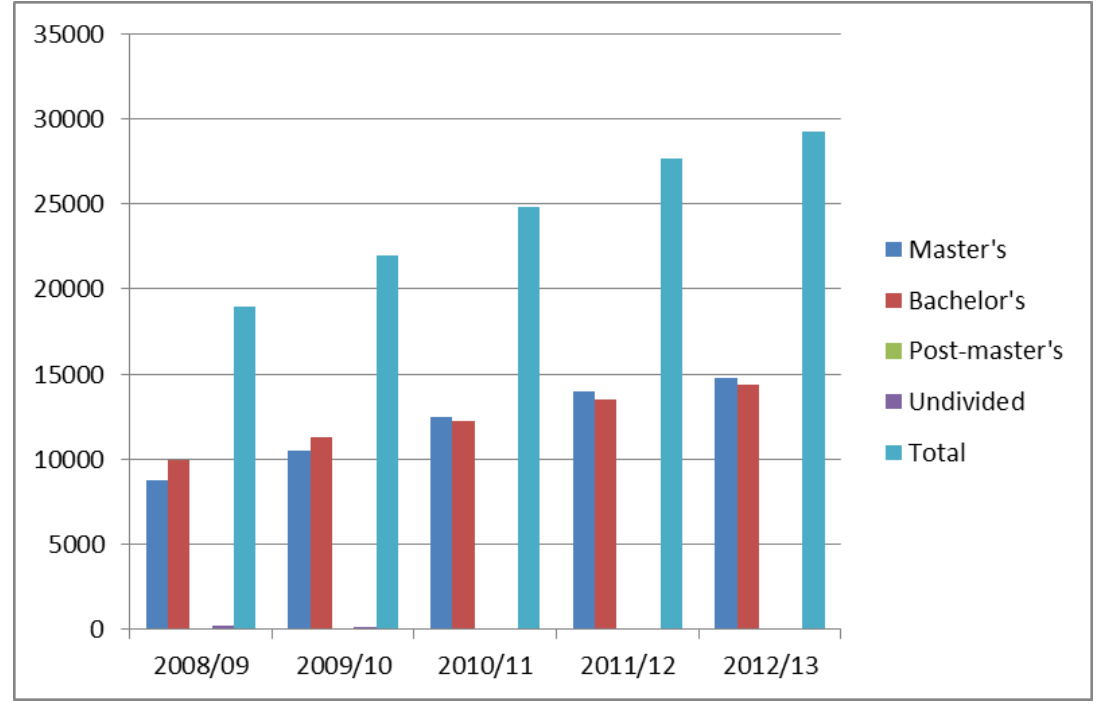

Source: Nuffic, 2014

Figure 3.4: Number of degree-mobile foreign students in HBOs by level of study in 2008-2013

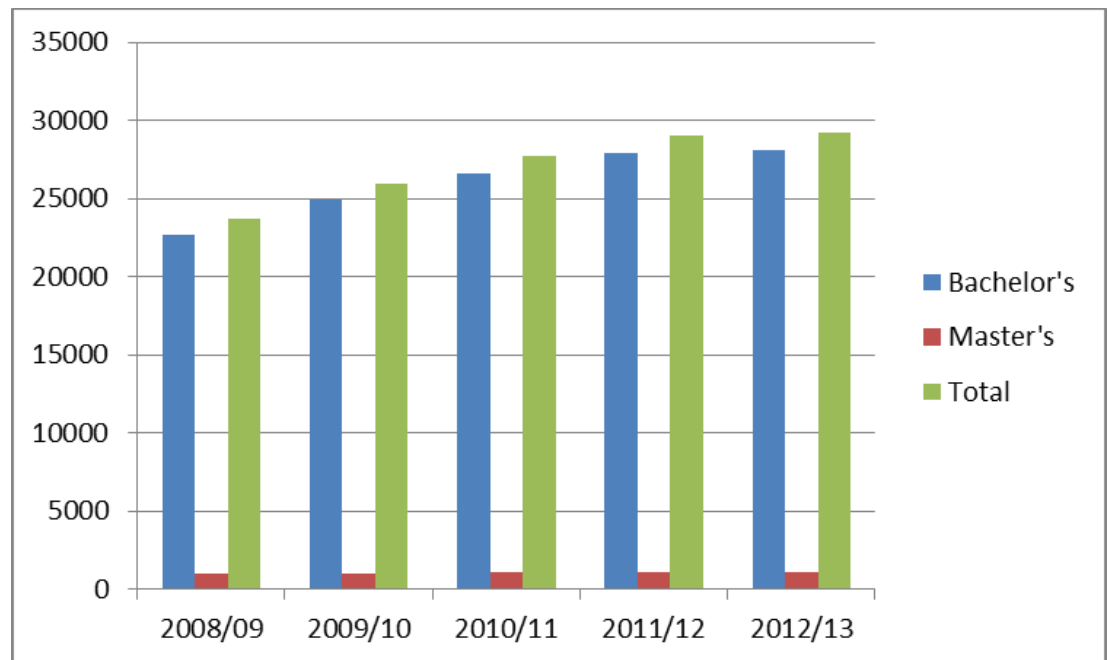

Source: Nuffic, 2014

Degree mobility by field of study

Foreign students in the Netherlands who enrolled to government-funded WOs are concentrated in several fields of study as reflected in Figure 3.5. Apart from cross- 
sectoral fields of studies where a third of all students are degree mobile students ${ }^{3}$, the share of degree mobile students in 2012/2013 is particularly high in agriculture and natural environment studies (23.6\%) and economics $(21.2 \%)$. The increase in degree mobility in economics between 2008 and 2013 is spectacular: it rose from $15.2 \%$ to $21.2 \%$.

Figure 3.5: Percentage share of foreign diploma students in WOs by field of study in 2008-2013

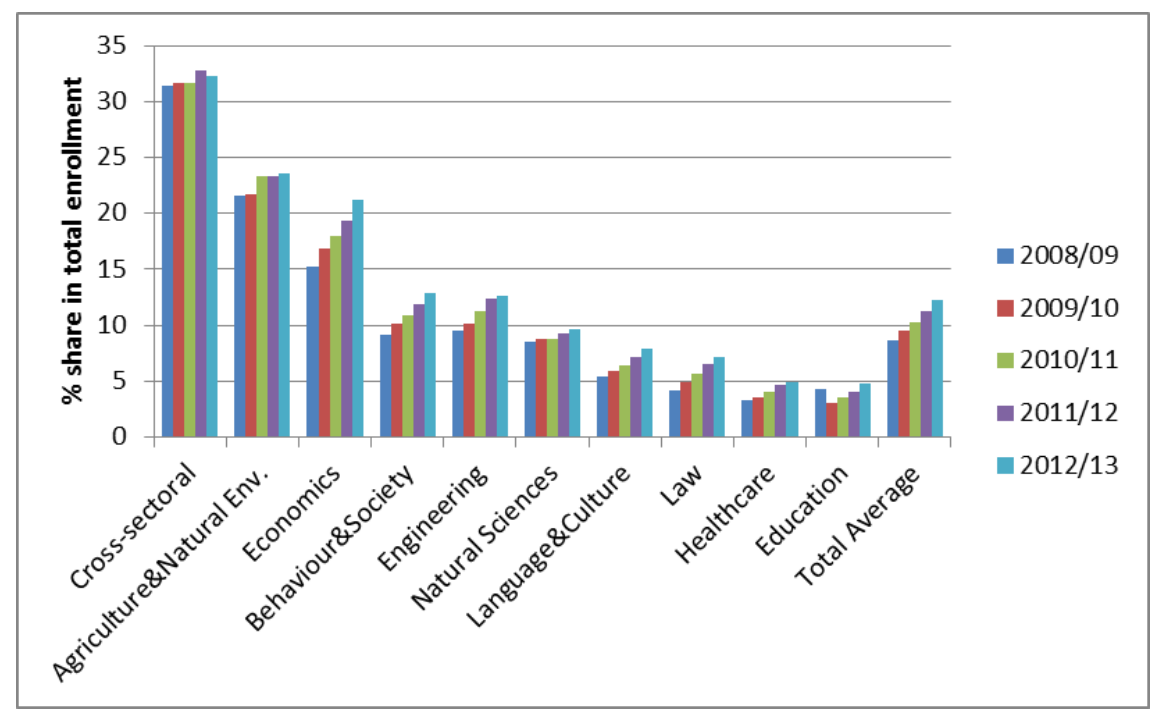

Source: Nuffic, 2014

In government-funded HBOs, the share of foreign students is especially large in language and culture. Although it has exhibited a declining trend between 2008 and 2010 , the share of degree mobile students in that field equals $25 \%$ in 2012/2013 (Figure 3.6). In economics, the share of degree mobile students in universities of applied sciences has increased from $7.7 \%$ in 2008 to $9 \%$ in 2013.

\footnotetext{
${ }^{3}$ Note that is a relatively small field.
} 
Figure 3.6: Percentage share of foreign diploma students in HBOs by field of study in 2008-2013

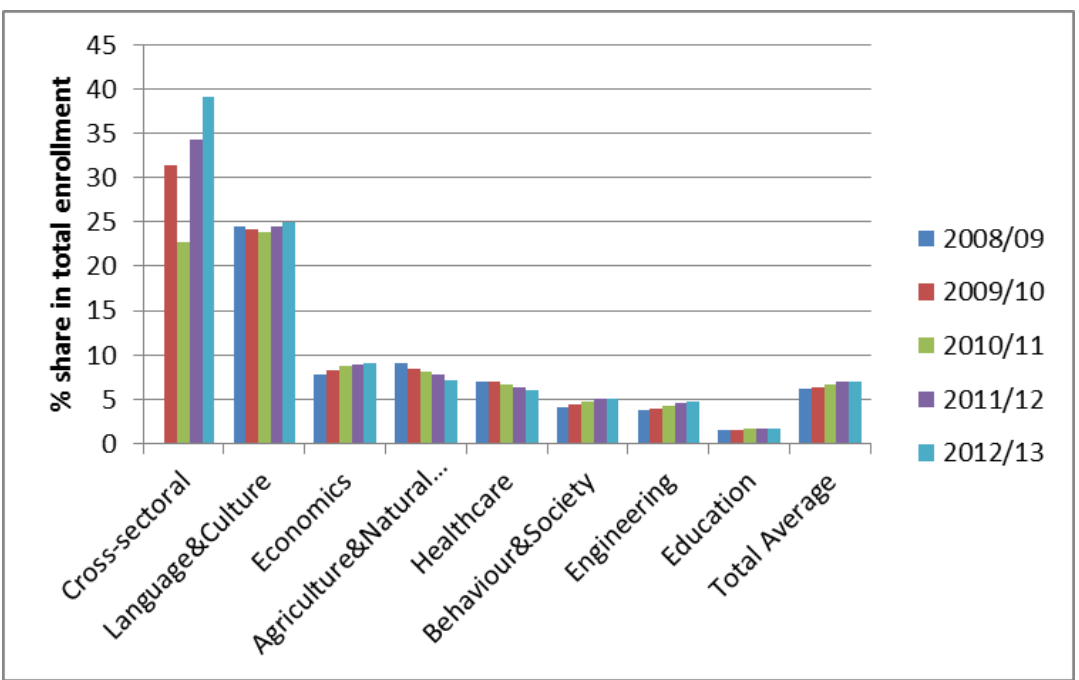

Source: Nuffic, 2014

\section{Sending countries}

The Netherlands has been receiving many foreign degree-mobile students from other European Union countries as Figure 3.7 shows. In particular, the Netherlands hosts large numbers of German students in part due to the geographical proximity and in part due to the good reputation of Dutch Universities. However, a large and increasing number of degree-mobile students come from China.

Figure 3.7: Top 8 countries of origin of foreign diploma students in the Netherlands in 2008-2013

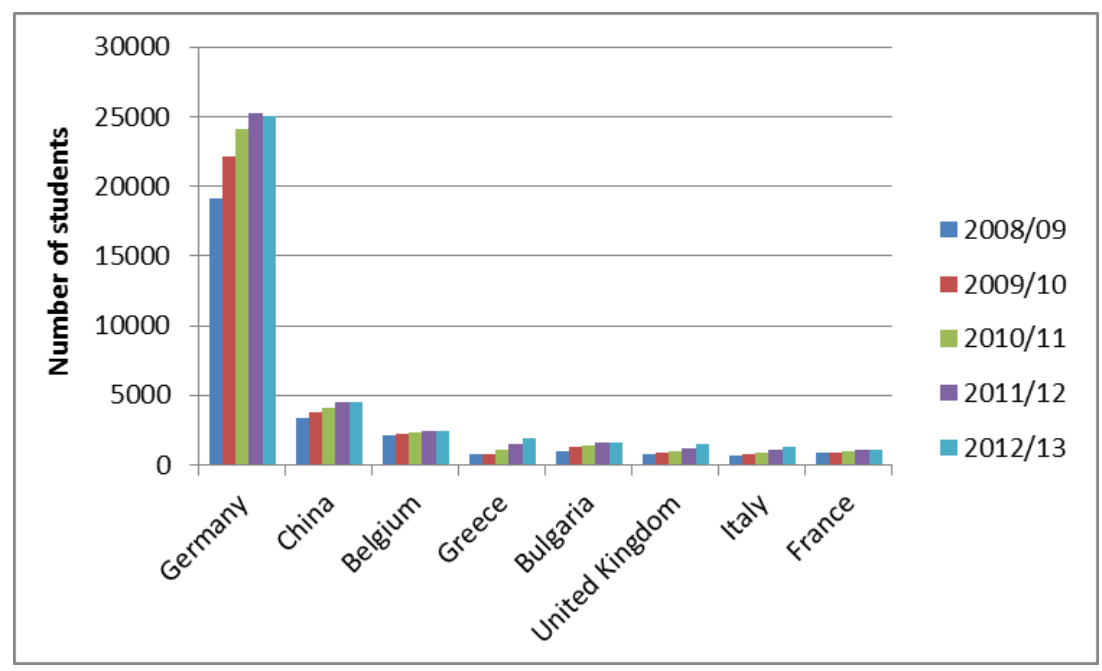

Source: Nuffic, 2014 
Incoming credit mobility

Although credit mobility is not expected to have a large impact on host countries' labour market ${ }^{4}$, we now briefly discuss recent trends in incoming credit mobility. Just like the number of degree-mobile students, the number of credit-mobile students has also been increasing since 2005, especially between 2007/08 and 2010/11 (Figure 3.8). The number of incoming credit-mobile students under the Erasmus program increased by almost $20 \%$ from $2007 / 08$ to $2012 / 13$.

Figure 3.8: Number of inbound Erasmus students in the Netherlands in 20052013

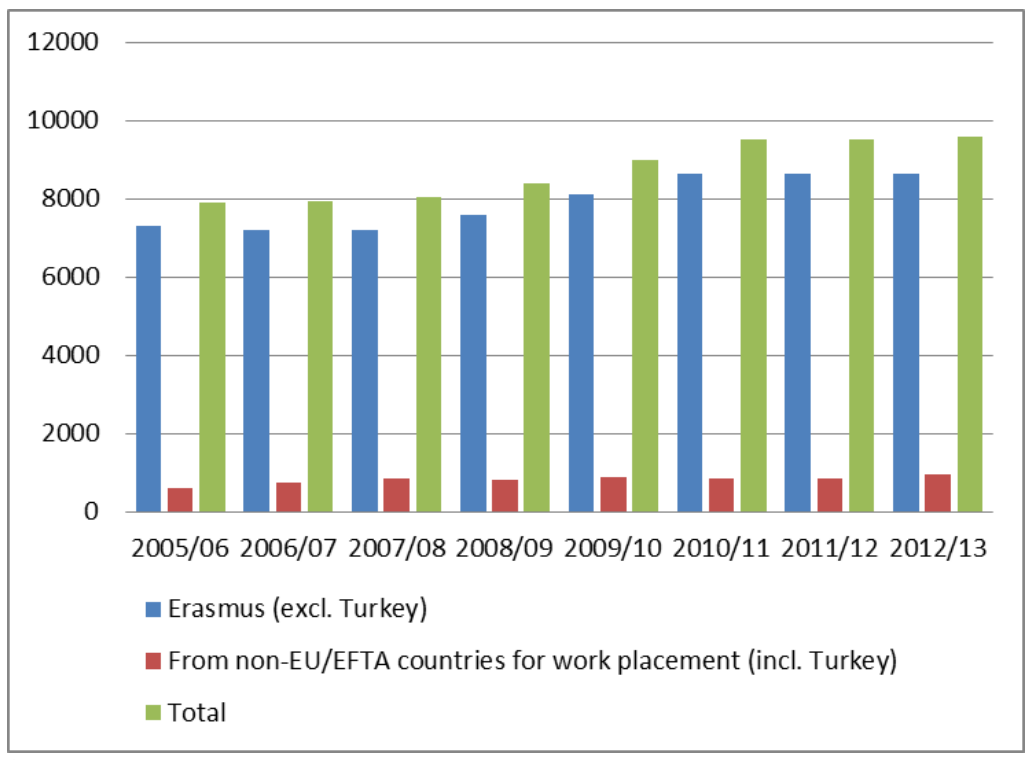

Source: Nuffic, 2014

${ }^{4}$ The average stay of a degree mobile student is only 6 months (European Commission 2012). 
Figure 3.9: Percentage of total Erasmus population who prefer the Netherlands - for top 5 countries with the highest percentage in 2006-2011

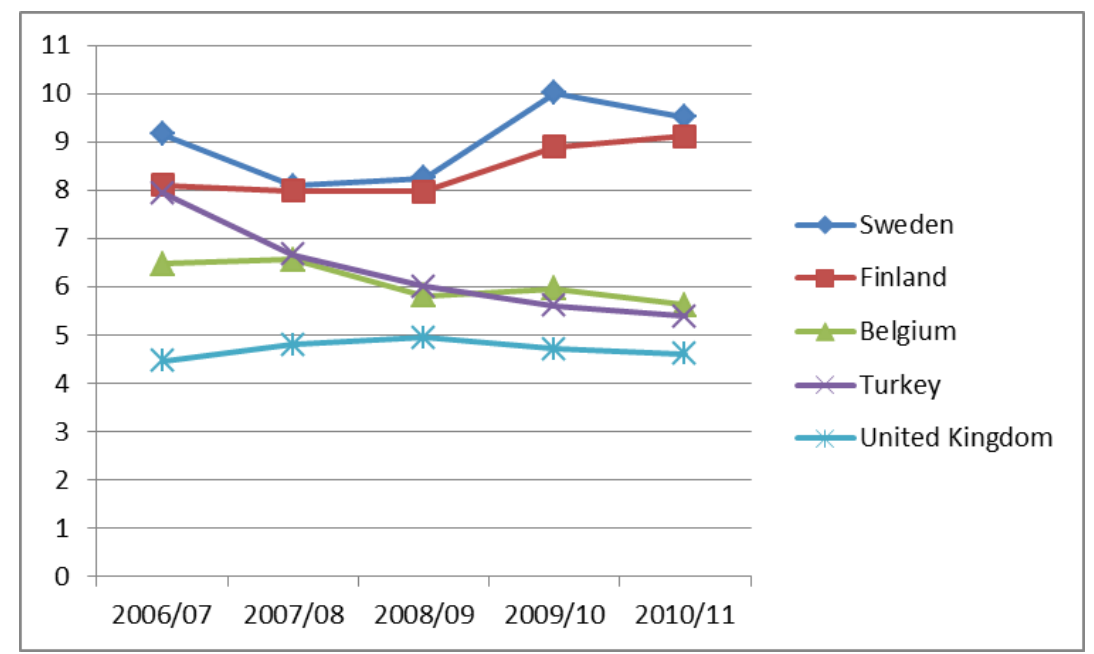

Source: Nuffic, 2014

When looking at absolute numbers, Spain, France, Germany, Italy, and Turkey seem as the main sending countries (Nuffic, 2014). However, considering the share of exchange students in the total Erasmus population in a country who prefer coming to the Netherlands, Sweden, Finland, Belgium, Turkey, and United Kingdom are among the main student-sending countries (Figure 3.9).

\subsection{Outgoing student mobility}

Although outbound student mobility is lower in size compared to inbound student mobility in the Netherlands, an increasing trend in outbound student mobility is visible in recent years. As shown in Figure 3.10, outbound student mobility in the Netherlands has increased by 47\% between 2005 and 2011. This increase has been driven by both degree- and credit-mobile students while increase in outbound credit mobility is slightly higher in the same period (almost 50\%). 
Figure 3.10: Number of outgoing students in the Netherlands in 2005-2011

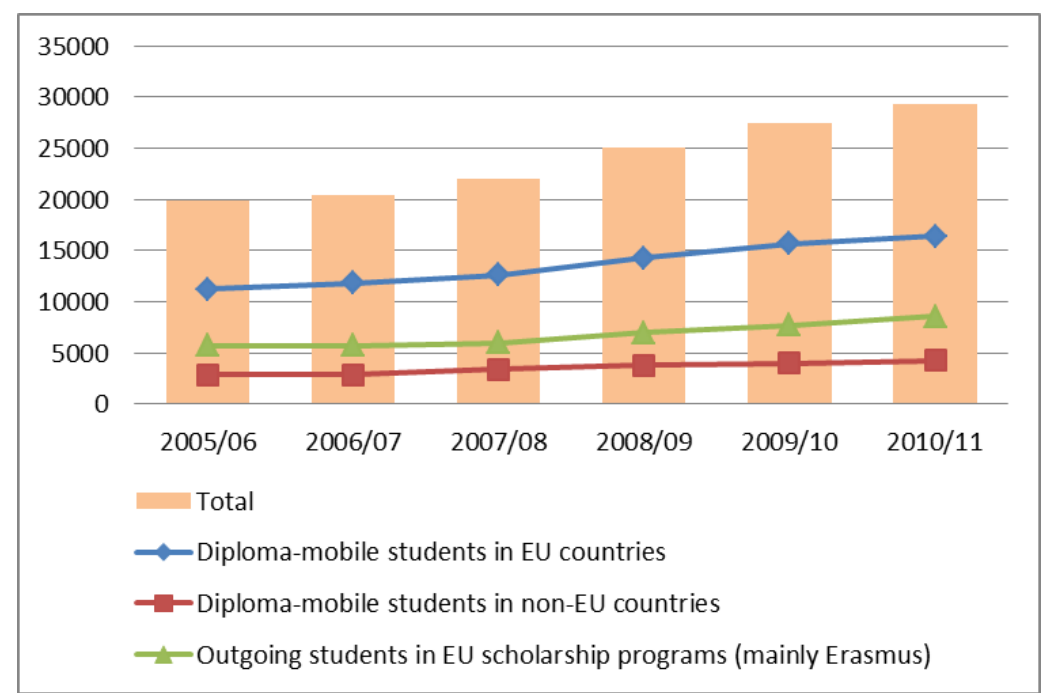

Source: Nuffic, 2014

\section{Outgoing degree mobility}

Between 2006 and 2011, the number of degree-mobile Dutch students increased by $40 \%$ to almost 21,000 as reflected by Figure 3.10. Outgoing Dutch degree-mobile students constituted slightly more than $3 \%$ of total enrolment in Dutch universities after 2009. 
Figure 3.11: Number of Dutch degree-mobile students abroad and percentage share in total enrolment in the Netherlands in 2006-2011

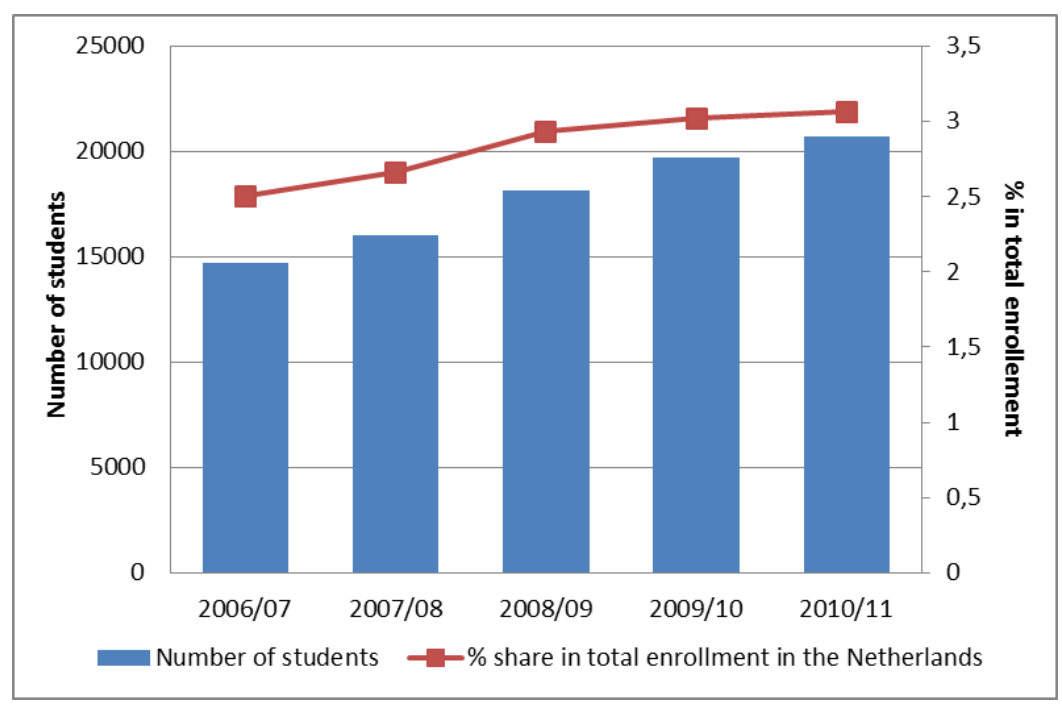

Source: Nuffic, 2014

Figure 3.12: Top 6 destinations of Dutch degree-mobile students in 2006-2011 (in absolute numbers)

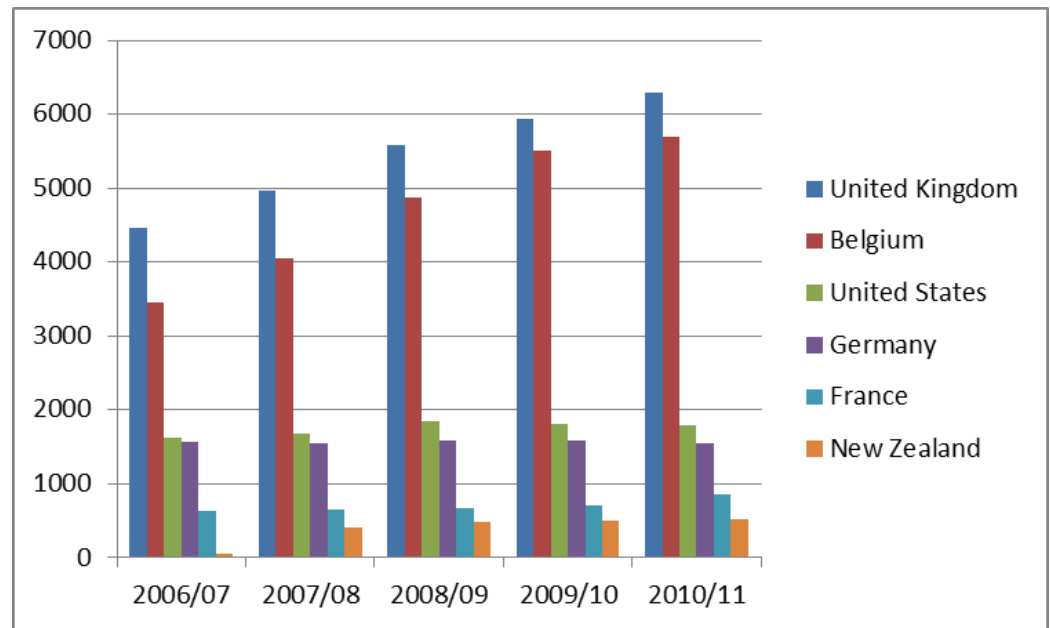

Source: Nuffic, 2014

The most preferred destination countries of Dutch degree-mobile students are presented in Figure 3.12. In the period of 2006-2011, the number of Dutch students going to United Kingdom, Belgium, and New Zealand increased faster than the number of students choosing for United States and France for their studies. In the same period, a slight decrease in number of students going to Germany can be observed. 


\section{Outgoing credit mobility}

Similar to the increasing trend in outbound degree-mobility in the Netherlands, outbound credit mobility has also increased in recent years as shown by Figure 3.13. As mentioned above, outbound credit mobility increased by almost $50 \%$ in the Netherlands. On average in Europe, 4.3\% of the student population in 2010/2011 was participating in the Erasmus scheme (European Commission, 2013). This percentage was higher in the Netherlands (6.2\%). For comparison, the share of outbound credit mobility was $1.7 \%$ in the UK, $5.7 \%$ in Germany, and $6.5 \%$ in Belgium. Luxembourg has, with $34.2 \%$, the highest incidence of outbound credit mobility.

Figure 3.13: Number of outbound Dutch credit-mobile students in 2005-2011

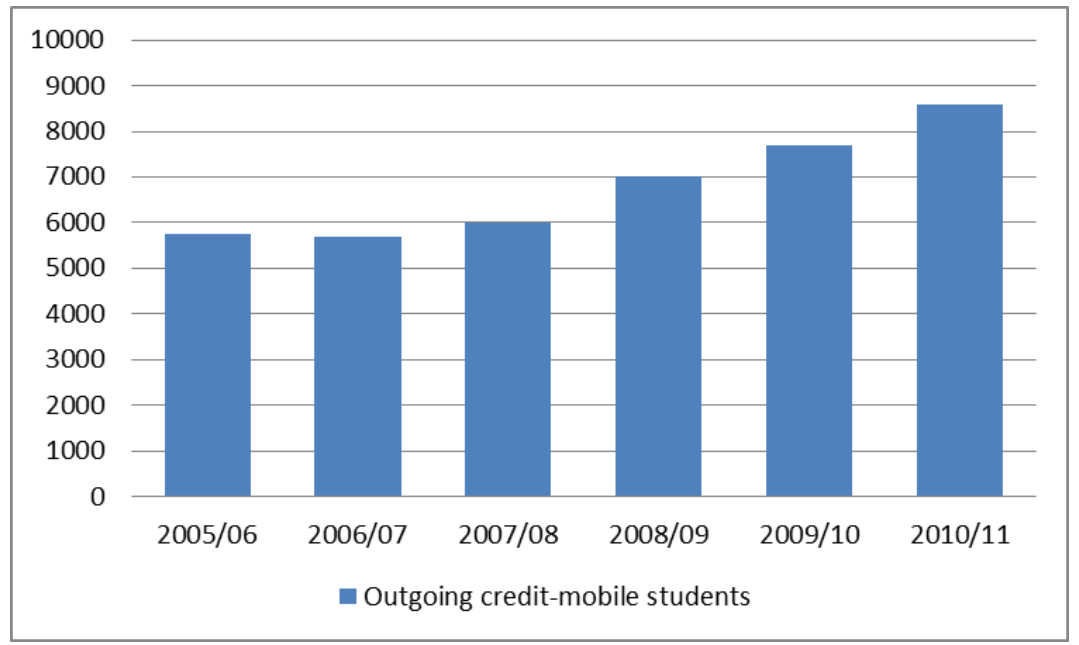

Source: Nuffic, 2014

Dutch university students enrolled in fields such as agriculture and natural environment, and engineering and healthcare are more inclined to participate into credit-mobility programs. For students in universities of applied sciences, outbound student mobility is most common in fields such as economics, language and culture, and agriculture and natural environment (Nuffic, 2012).

The main destination countries preferred by Dutch credit-mobile students are presented in Figure 3.14. Spain, United Kingdom and Germany are among the countries that have been increasingly receiving Dutch students in recent years. 
Figure 3.14: Top 5 destinations of Dutch Erasmus students (100 or more Erasmus students) in 2007-2012

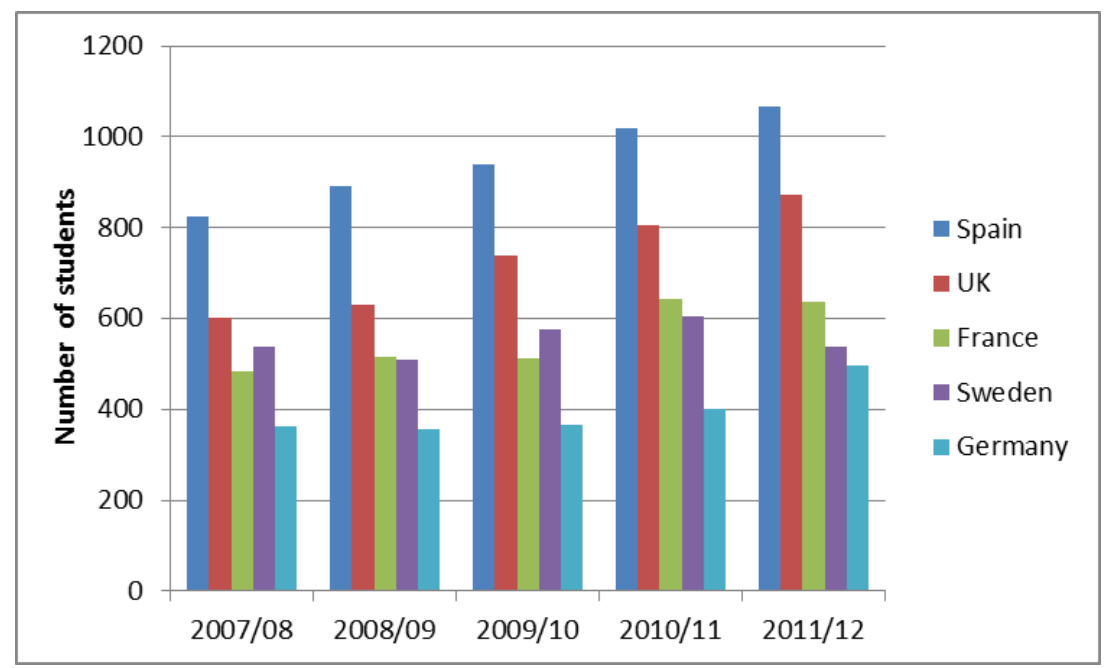

Source: Nuffic, 2014

\subsection{Net study migration}

The data discussed in this chapter show that the Netherlands receives considerable amount of degree-mobile and credit-mobile students, and that these numbers have been increasing. All in all, the share of degree mobile students is particularly high is specific fields of study. Degree mobility among Dutch students has also been increasing in recent years, similar to the trend observed all over the world. However, the figures above reflect that the Netherlands is still a net student-receiving country despite the increasing outbound mobility among Dutch students. In 2010/2011, the latest available year with data on both incoming and outgoing degree mobility, more than 52,000 students from outside the Netherlands were enrolled in Dutch higher education. In that year, about 20,600 Dutch students were studying abroad. 


\section{Sensitivity of labour markets forecasts to study migration}

\subsection{Inflow of graduates and degree migration}

With its labour market forecasts model, ROA quantifies the expected demand and supply by education and occupation over a six year-period. The confrontation of future demand and supply is used to derive an indicator for the discrepancy between the two (ROA, 2014). This discrepancy indicator - the Indicator Toekomstige Arbeidsmarktperspectieven (ITA) - can be viewed as an early warning imbalances between demand and supply on the labour market. The ITA is the ratio of expected supply to expected demand in 6 years from now:

$\operatorname{IT} A_{e, t+6}=\frac{L_{e, t}+U_{e, t}+I_{e, t: t+6}}{L_{e, t}+O_{e, t: t+6}+S_{e, t: t+6}}$,

where $e$ stands for various types of education defined by level and field of study, $L_{e, t}$ is the number of people employed in $t$ for education type $e, U_{e, t}$ is the number of people who are short-term unemployed in $t$ for education type $e, I_{e, t: t+6}$ is the expected inflow of graduates from education type $e$ in the next 6 years, $O_{e, t: t+6}$ is the expected number of job openings for people with education type $e$ in the next 6 years (it is the sum of the replacement demand and the positive expansion demand, see ROA, 2014), and $S_{e, t: t+6}$ is the expected substitution demand for people with education type $e$ in the next 6 years. ${ }^{5}$

It is obvious that both supply and demand by type of education determine the perspectives for a particular type of education $e$. When the expected supply exceed the expected demand, i.e. when ITA $>1$, then the labour market prospects are bad. This does not mean that young graduates by definition will face unemployment. There are other mechanisms for adjusting to such imbalance between supply and demand. For example, young graduates could seek employment in jobs below their education level, in other fields, accept lower wage offers or jobs with few secondary benefits, or even migrate abroad to seek employment.

In the latest labour market forecasts by ROA (2013) it is concluded that the prospects for young graduates from university and university of applied sciences are, on average, poor. Although these prospects differ strongly by field of study, the driving factors behind these poor prospects are 1) the absence of job growth due to the lasting economic crisis, 2) the low replacement due to the increased labour market

\footnotetext{
${ }^{5}$ The ITA can also be calculated from percentages or proportions by dividing all the terms by the current labour supply $L_{e, t}:$ IT $A_{e, t+6}=\frac{1+{ }^{U e, t} / L_{e, t}+{ }^{I_{e, t}: t+6} / L_{e, t}}{1+^{0_{e, t: t}+6} / L_{e, t}+{ }^{S_{e, t}: t+6} / L_{e, t}}$. This shows that the expected inflow of graduates is an important component of the future labour supply (about $88 \%$ of the total expected supply).
} 
participation at older ages, and 3) the high expected inflow of graduates possibly because of delayed entry in the labour market (Fouarge and Meng, 2014).

ROA's labour market inflow forecasts by type of education are derived from forecasts by the Ministry of education (Ministerie van Onderwijs, Cultuur en Wetenschap, 2013). These forecasts include foreign students enrolled at Dutch higher education institutions. One could therefore wonder to what extent the forecasts are sensitive to inclusion of these degree migrants. This is especially relevant in the light of the rising internationalisation in higher education, and the large differences in the incidence of degree migration across fields of study.

\section{Rational for including degree migration in inflow forecasts}

The implicit assumption in calculating the expected inflow $\left(I_{e, t: t+6}\right)$ is that, ex ante, all degree migrants are here to stay. It should be noted, however, that including degree migration in the inflow forecasts makes much sense from the point of view of the potential contribution of foreign students to the Dutch labour market as discussed in Section 2. For employers, study migrants constitute a pool of potential workers from which they can hire those with the skills required to fill their vacancies. From Dutch graduate's point of view this means they potentially have to compete with degree migrants for the jobs on the Dutch labour market. If labour is scarce, employers will make interesting job offers in order to attract recent graduates, including degree migrants. In case of oversupply on the Dutch labour market, one could expect degree migrants to seek employment elsewhere, but also Dutch students could adopt this strategy in order to improve their employment prospects. Ex ante, degree migrants impact on the expected labour market prospects of natives.

\section{Inflow corrected for degree migration}

Nevertheless, one can test the sensitivity of the labour market forecasts by accounting for differences in the incidence of degree migration across fields of study as reported in Section 3. For this purpose, we computed alternative measures for the inflow $\left(I_{e, t: t+6}\right)$, where we discount the forecasted inflow for the share of degree migrants by field of study, and the expected retention of degree migrants after completion of their study:

$I_{e, t: t+6}^{*}=I_{e, t: t+6}-\left(I_{e, t: t+6} * m_{e, t} *\left(1-r_{e, t}\right)\right)$,

where $m_{e, t}$ stands for the share of study migrants in field of study $e$ at time $t$, and $r$ is the retention rate. If there are no migrants in a specific field of study $\left(m_{e, t}=0\right)$ or if the all degree migrants stay on the Dutch labour market $\left(r_{e, t}=1\right)$, then $I_{e, t: t+6}^{*}=$ $I_{e, t: t+6}$. In other cases, $I_{e, t: t+6}^{*}<I_{e, t: t+6}$, and the 'overestimation' of the inflow will depend on both the incidence of degree migration and the retention rate of migrants. ${ }^{6}$

\footnotetext{
${ }^{6}$ Note that the inflow could be corrected upward for Dutch students who study abroad since they are not included in the forecasts by the Ministry of Education. However, we disregard these students because of the low incidence of degree mobility (only $3 \%$ of Dutch students go abroad
} 
The incidence of degree migration by fields of study is taken from Nuffic (2014). This data is discussed in Section 3, and makes the distinction between degree migration among university graduates and graduates from university of applied sciences. The retention rate is not available by field of study. Instead, we use the estimates reported in Section 3. The lower bound estimate suggests the retention is only $19 \%$ $\left(r_{e, t}=0.19\right)$. Other estimates suggest a retention rate of $43 \%\left(r_{e, t}=0.43\right)$. In addition we compute the inflow under the assumption that none of the degree migrants supply their labour on the Dutch labour market $\left(r_{e, t}=0\right)$. We compare the forecasted inflow and the ITA under these various assumptions to the ITA from the original forecasts from ROA (2013) that assume that ex ante $r_{e, t}=1$.

\subsection{Sensitivity of forecasts}

Table 1 reports on the sensitivity of the labour market forecasts for degree migration among graduates from university of applied sciences and university graduates. The ITA, as reported in ROA (2013), equals 1.12 for university of applied sciences and 1.11 for university graduates, which is indicative of poor labour market prospects. Assuming that all degree mobile graduates from university of applied sciences leave the Netherlands upon graduation would reduce the expected inflow until 2018 by $8.1 \%$. For the inflow from university, this would reduce the total inflow by $13.2 \%$. Although this extreme assumption does reduce the ITA, the labour markets prospects until 2018 would still be poor. Obviously, other assumptions with respect to the retention rate of degree migrants lead to a lower reduction of the inflow $(7.3 \%$ lower inflow from university), and have no impact on the forecasts.

to obtain a degree), and because there are no data to on outgoing degree mobility by field of study. 
Table 1: Sensitivity of inflow and ITA for university of applied science and university graduates, 2013-2018

\begin{tabular}{lcc}
\hline$\quad$ & $\begin{array}{c}\text { University of applied } \\
\text { sciences } \\
\text { (HBO) }\end{array}$ & $\begin{array}{c}\text { University } \\
\text { (WO) }\end{array}$ \\
\hline $\begin{array}{l}\text { Original forecasts }{ }^{1)} \\
\quad \text { ITA }\end{array}$ & 1.12 & 1.11 \\
$\quad$ Characterisation ITA & poor & poor \\
$r_{e, t}=0$ & -8.1 & -13.2 \\
$\quad$ Change in inflow (\%) & 1.10 & 1.08 \\
ITA & poor & poor \\
$\quad$ Characterisation ITA & & -10.7 \\
$r_{e, t}=0.19$ & -6.5 & 1.09 \\
$\quad$ Change in inflow (\%) & 1.10 & poor \\
ITA & poor & \\
$\quad$ Characterisation ITA & & -7.3 \\
$r_{e, t}=0.43$ & -4.4 & 1.10 \\
Change in inflow (\%) & 1.11 & poor \\
ITA & poor &
\end{tabular}

1) $\mathrm{ROA}$ (2013: p. 14)

As discussed in Section 3, degree migration strongly differs across fields of study, so it is possible that discount for it would affect some fields of study more than others. Table 2 shows for graduates from university of applied sciences that correcting for degree migration has a large impact on the forecasted inflow for studies that attract large numbers of foreign students such as economics, social-cultural sciences, and green studies. However, only for the latter does the correction for degree migration affect the forecasts, but only under the assumption of zero retention. 
Table 2: Sensitivity of inflow and ITA for graduates from university of applied sciences, 2013-2018

\begin{tabular}{|c|c|c|c|c|c|c|}
\hline & $\begin{array}{c}\text { HBO } \\
\text { onderwijs }\end{array}$ & $\begin{array}{c}\text { HBO } \\
\text { sociaal- } \\
\text { cultureel }\end{array}$ & $\begin{array}{l}\mathrm{HBO} \\
\text { groen }\end{array}$ & $\begin{array}{c}\text { HBO } \\
\text { techniek }\end{array}$ & $\begin{array}{c}\mathrm{HBO} \\
\text { paramedisch }\end{array}$ & $\begin{array}{c}\mathrm{HBO} \\
\text { economie }\end{array}$ \\
\hline \multicolumn{7}{|l|}{ Original forecasts ${ }^{1)}$} \\
\hline $\begin{array}{l}\text { ITA } \\
\text { Characterisation }\end{array}$ & 1.00 & 1.21 & 1.01 & 1.02 & 1.10 & 1.21 \\
\hline ITA & good & bad & fair & fair & poor & bad \\
\hline $\begin{array}{l}r_{e, t}=0 \\
\quad \text { Change in inflow } \\
(\%)\end{array}$ & -5.6 & -10.9 & -7.1 & -4.8 & -6.0 & -9.0 \\
\hline $\begin{array}{l}\text { ITA } \\
\text { Characterisation }\end{array}$ & 0.99 & 1.18 & 1.00 & 1.02 & 1.09 & 1.19 \\
\hline ITA & good & bad & good & fair & poor & bad \\
\hline $\begin{array}{l}r_{e, t}=0.19 \\
\text { Change in inflow } \\
(\%)\end{array}$ & -4.5 & -8.9 & -5.8 & -3.9 & -4.9 & -7.3 \\
\hline $\begin{array}{l}\text { ITA } \\
\text { Characterisation }\end{array}$ & 0.99 & 1.19 & 1.00 & 1.02 & 1.09 & 1.19 \\
\hline $\begin{array}{c}I T A \\
r_{e, t}=0.43\end{array}$ & good & bad & good & fair & poor & bad \\
\hline $\begin{array}{l}\text { Change in inflow } \\
(\%)\end{array}$ & -3.1 & -6.0 & -3.9 & -2.6 & -3.3 & -4.9 \\
\hline $\begin{array}{l}\text { ITA } \\
\text { Characterisation }\end{array}$ & 1.00 & 1.20 & 1.00 & 1.02 & 1.10 & 1.20 \\
\hline ITA & good & bad & good & fair & poor & bad \\
\hline
\end{tabular}

For university graduates, where degree migration is high for green studies and economics, correcting for degree mobility reduces the expected inflow, but this has no effect on the characterisation of the ITA (Table 3). 
Table 3: Sensitivity of inflow and ITA for university graduates, 2013-2018

\begin{tabular}{|c|c|c|c|c|c|}
\hline & $\begin{array}{l}\text { WO } \\
\text { letteren } \\
\text { en } \\
\text { sociaal- } \\
\text { cultureel }\end{array}$ & WO groen & $\begin{array}{c}\text { WO } \\
\text { techniek }\end{array}$ & $\begin{array}{l}\text { WO } \\
\text { medisch }\end{array}$ & $\begin{array}{c}\text { WO } \\
\text { economie } \\
\text { en recht }\end{array}$ \\
\hline \multicolumn{6}{|l|}{ Original forecasts $^{1)}$} \\
\hline $\begin{array}{l}\text { ITA } \\
\text { Characterisation }\end{array}$ & 1.10 & 1.14 & 1.03 & 1.00 & 1.24 \\
\hline ITA & poor & poor & fair & good & bad \\
\hline $\begin{array}{l}r_{e, t}=0 \\
\text { Change in inflow } \\
(\%)\end{array}$ & -11.7 & -23.6 & -12.6 & -4.9 & -16.2 \\
\hline $\begin{array}{l}\text { ITA } \\
\text { Characterisation } \\
\text { ITA }\end{array}$ & poor & $\begin{array}{l}1.07 \\
\text { poor }\end{array}$ & $\begin{array}{l}1.01 \\
\text { fair }\end{array}$ & $\begin{array}{l}0.99 \\
\text { good }\end{array}$ & $\begin{array}{l}1.19 \\
\text { bad }\end{array}$ \\
\hline $\begin{array}{l}r_{e, t}=0.19 \\
\text { Change in inflow } \\
(\%)\end{array}$ & -9.4 & -19.1 & -10.2 & -4.0 & -13.1 \\
\hline $\begin{array}{l}\text { ITA } \\
\text { Characterisation } \\
\text { ITA }\end{array}$ & 1.08 & 1.08 & 1.01 & 0.99 & $\begin{array}{l}1.2 \\
\text { bad }\end{array}$ \\
\hline $\begin{array}{l}r_{e, t}=0.43 \\
\quad \text { Change in inflow } \\
(\%)\end{array}$ & -6.4 & -13.0 & -6.9 & -2.7 & -8.9 \\
\hline $\begin{array}{l}\text { ITA } \\
\text { Characterisation } \\
\text { ITA }\end{array}$ & poor & 1.10 & 1.02 & 0.99 & 1.21 \\
\hline
\end{tabular}

1) ROA (2013: 67)

For some specific fields of study, the correction for degree migration does have a relatively large impact on the inflow. Under the extreme assumption that none of the degree migrants remain on the Dutch labour market, the inflow drops with $23.6 \%$ for university graduates in environmental science, while it drops with $21.2 \%$ for university graduates in business administration and economics. All in all, even in this extreme case, the perspectives only improve for three fields of study (the average reduction of the ITA equals 0.02). The perspectives for $\mathrm{HBO}$ environmental sciences and food technology switch from poor to fair with a reduction of the ITA of only .01 point. The perspectives for HBO (physio)therapy switch from bad to poor with a reduction of the ITA change by .02 point. The perspectives for WO economics/econometrics switch from bad to poor with a reduction of the ITA by .06 point. 


\section{Conclusion}

In this report, we have looked into the labour market contribution of study migration, the extent of study migration in the Netherlands, and the implication of including study migration in ROA's labour market forecasts. From the literature review, we conclude that study migration is a potential source of qualified labour market supply, and nations spend much effort in attracting study migrants. The scant literature on the retention of degree mobile students reports on estimates of the retention rate ranging from $19 \%$ to $43 \%$. We have then quantified the extent of degree mobility in the Netherlands. We have shown that inbound degree mobility has been increasing in the Netherlands, and that the international mobility of Dutch students has also been increasing. However, study mobility varies significantly across fields of study: it is especially high in fields such as economics and natural sciences. Another lesson from the literature review is that we actually know little about the retention rate of study migrants by field of study. It is also unknown to what extent the retention of international students varies over the business cycle.

In ROA's labour market forecasts degree migrants are counted as inflow in the Dutch labour market. The rationale for doing so is that Dutch employers can actually draw from this potential labour supply. Nevertheless, the sensitivity of the mid-term forecasts to the inclusion of the large and growing group of degree migrants has never been tested. In this report, we made several assumptions with respect to the retention of degree migrants. We showed that degree migration, although it can have a significant impact on the number of graduates counted as inflow in the Dutch labour market, hardly affects the labour market forecasts for the discrepancy between labour supply and labour demand. 


\section{References}

Abella, M., 2006. Global Competition for Skilled Workers. In: C. Kuptsch \& E. Pang, eds. Competing for Global Talent. Geneva: International Labour Organization, pp. 11-32.

Aslanbeigui, N. \& Montecinos, V., 1998. Foreign Students in U.S. Doctoral Programs. Journal of Economic Perspectives, 12(3), pp. 171-182.

Barucha, Y., Budhwarb, P. S., \& Khatric, N., 2007. Brain Drain: Inclination to Stay Abroad After Studies. Journal of World Business, 42(1), pp. 99-112.

Becker, R. \& Kolster, R., 2012. International Student Recruitment: Policies and Developments in Selected Countries, The Hague: Nuffic.

Bijwaard, G., 2010. Immigrant Migration Dynamics Model for The Netherlands. Journal of Population Economics, 23(4), pp. 1213-1247.

Borjas, G., 2004. Do Foreign Students Crowd Out Native Students from Graduate Programs? NBER Working Paper No. 10349.

Bratsberg, B., 1995. The Incidence of Non-Return Among Foreign Students in the United States. Economics of Education Review, 14(4), pp. 373-384.

Centraal Planbureau, 2012. CPB Notitie: De Economische Effecten van Internationalisering in het Hoger Onderwijs, Den Haag: Centraal Planbureau.

Chellaraj, G., Maskus, K. \& Mattoo, A., 2008. The Contribution of International Graduate Students to US Innovation. Review of International Economics, 16(3), pp. 444-462.

Choudaha, R., \& Chang, L., 2012. Trends in international student mobility. World Education News \& Reviews, 25(2).

de Grip, A., Fouarge, D. \& Sauermann, J., 2010. What Affects International Migration of European Science and Engineering Graduates?. Economics of Innovation and New Technology, 19(5), pp. 407-421.

European Commission, 2012. Lifelong Learning Programme. THE ERASMUS PROGRAMME 2010-2011. A Statistical Overview.

European Commission, 2013. On the way to ERASMUS+: A Statistical Overview of the ERASMUS Programme in 2011-12, Brussels: European Commission.

European Commission, 2014. Erasmus+ Program Study Mobility. [Online] 
Available at: http://ec.europa.eu/education/opportunities/higher-education/studymobility en.htm [Accessed 0206 2014].

Finn, M. G., 2014. Stay Rates of Foreign Doctorate Recipients from U.S. Universities, 2011. Oak Ridge Institute for Science and Education.

Fouarge, D. \& C. Meng (2014). Jongeren in de knel op de arbeidsmarkt. THEMA, 3 , pp. 6-12.

Fouarge, D., \& Thor, J. van (2011). Studiemigratie. In: R.P.W. Jennissen (ed.), De Nederlandse migratiekaart: Achtergronden en ontwikkelingen van verschillende migratietypen. Den Haag: Boom Juridische uitgevers (pp. 111-147).

Gaulé, P. \& Piacentini, M., 2013. Chinese Graduate Students and U.S. Scientific Productivity. The Review of Economics and Statistics, 95(2), pp. 698-701.

Gibson, J., \& McKenzie, D., 2011. Eight Questions about Brain Drain. Journal of Economic Perspectives, 25(3), pp. 107-128.

González, C., Mesanza, R. \& Mariel, P., 2011. The Determinants of International Student Mobility Flows: An Empirical Study on the Erasmus Programme. Higher Education, 62(4), pp. 413-430.

Gribble, C., 2008. Policy Options for Managing International Student Migration: The Sending Country's Perspective. Journal of Higher Education Policy and Management, 30(1), pp. 25-39.

Grogger, J. \& Hanson, G., 2013. The Scale and Selectivity of Foreign-Born PhD Recipients in the US. American Economic Review, 103(3), pp. 189-92.

Gurmu, S., Black, G. \& Stephan, P., 2010. The Knowledge Production Function for University Patenting. Economic Inquiry, 48(1), pp. 192-213.

Hunt, J. \& Gauthier-Loiselle, M., 2010. How Much Does Immigration Boost Innovation?. American Economic Journal: Macroeconomics, 2(2), pp. 31-56.

Kahanec, M., \& Zimmermann, K. F., 2011. High-Skilled Immigration Policy in Europe. DIW Berlin Discussion Paper No.1096.

Kerr, S. P., \& Kerr, W. R., 2011. Economic Impacts of Immigration: A Survey. Finnish Economic Papers, 24(1), pp. 1-32.

Kerr, W., 2013. U.S. High-Skilled Immigration, Innovation, and Entrepreneurship: Empirical Approaches and Evidence. NBER Working Paper 19377.

Kerr, W. \& Lincoln, W., 2010. The Supply Side of Innovation: H-1B Visa Reforms and US Ethnic Invention. NBER Working Paper 15768. 
Lee, J. J., \& Kim, D., 2010. Brain Gain or Brain Circulation? U.S. Doctoral Recipients Returning to South Korea. Higher Education, 59(5), pp. 627-643.

Ministerie van Onderwijs, Cultuur en Wetenschap, 2013. Referentieraming 2013, Zoetermeer.

Münch, C. \& Hoch, M., 2013. The Financial Impact of Cross-border Student Mobility on the Economy of the Host Country, Berlin: DAAD.

NAFSA, 2013. The Economic Benefits of International Students to the U.S. Economy. Washington, D.C.: NAFSA.

Nuffic, 2012. Mapping Mobility in 2012: International Mobility in Dutch Higher Education, The Hague: Nuffic.

Nuffic, 2013. Study in Holland. [Online]

Available at: http://www.studyinholland.nl/education-system/get-value-for-money

[Accessed 0206 2014].

Nuffic, 2014. Internationalisering in Beeld 2013. The Hague: Nuffic.

OECD, 2011. Education at a Glance 2011: OECD Indicators. OECD.

OECD, 2013. Education at a Glance 2013: OECD Indicators. OECD.

Parey, M., \& Waldinger, F., 2011. Studying Abroad and the Effect on International Labour Market Mobility: Evidence from the Introduction of Erasmus. The Economic Journal, 121(551), pp. 194-222.

Rizvi, F., 2005. Rethinking "Brain Drain" in the Era of Globalisation. Asia Pacific Journal of Education, 25(2), pp. 175-192.

ROA, 2013. De arbeidsmarkt naar opleiding en beroep tot 2018. Maastricht: ROA-R2013/11.

ROA, 2014. Methodiek arbeidsmarktprognoses en -indicatoren 2013-2018. ROA-TR2014/3. Maastricht: ROA.

Straubhaar, T., 2000. International mobility of the highly skilled:Brain gain, brain drain or brain exchange. Hamburgisches Welt-Wirtschafts-Archiv Discussion Paper No.88.

Stuen, E., Mobarak, A. \& Maskus, K., 2012. Skilled Immigration and Innovation: Evidence from Enrollment Fluctuations in US Doctoral Programmes. The Economic Journal, 122(565), pp. 1143-1176. 
Sykes, B., \& Chaoimh, E. N., 2012. Mobile Talent? The Staying Intentions of International Students in Five EU Countries. Berlin: Sachverständigenrat deutscher Stiftungen für Integration und Migration.

Tremblay, K., 2005 . Academic Mobility and Immigration. Journal of Studies in International Education, 9(3), pp. 196-288.

U.S. Immigration and Naturalization Service, 2000. Characteristics of speciality occupation workers (H-1B). Washington, DC: U.S. Immigration and Naturalization Service.

Van Bouwel, L., \& Veugelers, R., 2013. The Determinants of Student Mobility in Europe: The Quality Dimension. European Journal of Higher Education, 3(2), pp. 172-190.

Varghese, N., 2008. Globalization of Higher Education and Cross-Border Student Mobility. Paris: International Institute for Educational Planning. 


\section{Appendix: Further dimensions of study mobility}

Study mobility have important implications not only in terms of host countries' labour market but also the whole economy in general. While opening higher education system to foreigners might bring some costs, these costs might be alleviated by contribution of students to the host country's economy in particular spheres of economic life. Literature on the potential impacts of student mobility guided us to evaluate the further dimensions of the issue based on the cost-benefit scheme provided in Figure A.1.

Figure A.1: Potential costs and benefits of student mobility

\begin{tabular}{|c|c|}
\hline \begin{tabular}{ll}
\multicolumn{1}{c}{ Costs } \\
- & Financial support to international \\
students \\
- $\quad$ Provision of a study place \\
- $\quad$ Consumption of imported \\
commodities \\
- Difficulties in teaching due to \\
language barriers and cultural \\
differences
\end{tabular} & \begin{tabular}{ll}
\multicolumn{1}{c}{ Benefits } \\
- & Impacts on labour market \\
- & Impacts on productivity \\
- & Consumption of domestic \\
commodities \\
- $\quad$ Impacts on fiscal balances due to \\
tuition fees, direct and indirect \\
taxes
\end{tabular} \\
\hline
\end{tabular}

It should be noted that the costs and benefits listed above might differ by type of mobility and level of study. For instance, costs and benefits associated with credit mobility are expected to be limited considering short duration of credit-mobile students in their host countries. Some of the items such as "benefits in terms of productivity" might not be applicable for credit mobile students when their concentration in bachelor's programs is taken into account while this item might be very associated with incoming foreign $\mathrm{PhD}$ students. On the other hand, the other impacts provided in the framework above might not be relevant for international PhDs if one considers that they are already a part of the labour market of their host countries since they are employed, involve in productive activities, and receive wages so they are already high skilled migrants rather than mobile students. Therefore, the functioning of cost and benefit channels listed in Figure A.1 should be separately evaluated for different groups of mobile students.

In brief, effects of study mobility on labour market constitute the objective of this study and already discussed in the main part of the report; thus, this section focuses on other costs and benefits associated with study mobility by taking the differentiation of costs and benefits by type of mobility and level of study into account. 


\section{A.1 Costs of student mobility}

\section{Financial support and provision of study place}

Two of the cost items associated with incoming foreign students are the financial support provided to international students and the cost of provision of study place which are discussed here together due to their relevance to each other.

These costs for incoming credit-mobile students are expected to be limited since those students are paid by their sending countries from the budget allocated under certain conditions set by the European Commission under Erasmus scheme (European Commission, 2013). In this respect, outbound credit mobility leads to a cost rather than inbound credit mobility for countries participating into Erasmus program.

On the other hand, it is not the case for inbound degree mobility. Normally, it is expected that incoming degree-mobile students in bachelor's and master's programs pay all of the fees regarding their enrolment and further studies in accordance with the rules set by higher education institutions or governments to finance higher education and these payments are expected to meet the cost of provision of study place. However, the cost that is normally borne by incoming students might be borne by other agents in higher education market when international students receive financial support from the host country for their studies. According to Münch and Hoch (2013), cost of provision per study place is $€ 10,500$ in the Netherlands. The annual tuition fee is around $€ 1,700$ in 2013 for Dutch students and this amount is also applicable to all EU students due the Bologna agreement (Nuffic, 2013). However, higher education institutions can charge higher fees for non-EU students ranging from $€ 5,200$ to $€ 9,600$ for bachelor's and $€ 10,000$ to $€ 20,000$ for master's degrees. Thus, fees, especially charged from EU students, seem not to cover the costs of study place provision. In addition, there are many scholarships for both EU and non-EU students at all degrees offered by Dutch universities, research centres, or Nuffic. ${ }^{7}$ Therefore, it could be argued that cost of provision of a study place for incoming degree-mobile students is mainly financed by the state in the Netherlands (Münch \& Hoch, 2013) and scholarships to attract foreign students bring extra costs to the Dutch economy.

\section{Consumption of imported commodities}

A national economy can both benefit and suffer from consumption of international students. The presence of international students creates extra demand for goods and services in the host country and this extra demand might push production and stimulate the creation of new jobs (Münch \& Hoch, 2013). However, it could be argued that preferences of those students over their consumption are also important: if foreign students' consumption expenditures are concentrated on imported goods and services, then increase in consumption might damage the balance of payments in a host country if everything else is assumed constant (Centraal Planbureau, 2012).

\footnotetext{
${ }^{7}$ For detailed information, see http://www.studyinholland.nl/scholarships/grantfinder
} 
Nevertheless, this effect might not be very large considering that students' consumption cannot be fully concentrated on imported goods and services since they need to meet certain needs in local markets (e.g., accommodation) and such an effect, if there is any, can also be lowered with indirect taxes charged on consumption.

\section{Language barriers and cultural differences}

Language barriers might have a negative impact on education quality (Centraal Planbureau, 2012). In the case of credit mobility, costs related to difficulties in teaching due to language barriers might not be very large (indeed, it may be essential to bear) in the sense that the main aim of Erasmus Program is already to enhance intercultural skills of students (European Commission, 2013). González et al. (2011) showed that host country language as a means of teaching does not have any discouraging effect on students' choosing those institutions for exchange studies. Thus, credit-mobile students might be open and motivated to learn different languages under such exchange schemes, suggesting that costs associated with differences in language and culture are not high.

Conversely, language barriers and cultural differences might be more problematic for degree-mobile students since their most important aim is to develop their professional knowledge in a certain field and to attain a degree. Van Bouwel and Veugelers (2013) showed that students at bachelor's and master's levels prefer going to English-speaking countries due to extensive use of English as worldwide scientific language. Thus, many European universities have initiated international degree programs taught in English to encourage student mobility. On the one hand, this can be a costly practice for individual teachers and teaching institution, especially in the start-up phase. On the other hand, increasing the number of English-taught programs at teaching institutions is less costly because of economies of scale. The increasing supply of English-taught programs can turn into an asset in attracting foreign students because language barriers are not a major cost item for potential degree migrants. The large and increasing availability of English-taught bachelor's and master's programs in the Netherlands is a likely explanation for the large share of degree-mobile students.

\section{A.2 Benefits of student mobility}

\section{Productivity}

In recent years, student mobility has been a growing market and higher education institutions compete to attract the best students. This competition might improve the education quality in higher education institutions through several ways. Firstly, competition between institutions might lead to a better match of students and institutions that results in improvements in productivity and quality of education (Centraal Planbureau, 2012). In addition, incoming students might contribute to the finance of higher education institutions by bringing economic resources (e.g., tuition fees) to be used in quality improvement (Tremblay, 2005). Furthermore, when 
incoming students perform better than native students, further quality improvements might be experienced due to peer effects (Centraal Planbureau, 2012).

Although attraction of international degree-mobile students contributes to quality improvement in host institutions in the ways mentioned above, their own contribution in terms of productivity might be limited since they are engaged in full-time education. Thus, the productivity contribution of study migration is mostly driven by international PhD students. International PhD students are already high-skilled migrants and expected to contribute to their host countries' productivity by conducting research activities in the form of dissertations which constitutes a part of R\&D activities in the host country (Tremblay, 2005). To the best of our knowledge, there is not any study concentrating on the productivity of foreign PhD students in the Netherlands or in Europe but there are several studies conducted in the U.S. context which show the degree of contribution of international $\mathrm{PhDs}$ in the form of academic publications, citations, patent applications or patent awards.

By using aggregate U.S. data on patent applications in the period of 1963-2001 and patent awards in the period of 1965-2001, Chellaraj et al. (2008) estimated the impact of foreign graduate students on patent applications and awards in academic and non-academic sectors through an idea generation model and found that a $10 \%$ increase in the share of foreign PhD students raise patent application by $4.5 \%$ and patent grants by $6.8 \%$ and $5.0 \%$ in academic and non-academic sectors, respectively. A more recent study conducted by Gurmu et al. (2010) by using university level data of patents issued in the period 1985-1999 reveals that increase in stock of postdocs with temporary visas has a significant positive impact on patents issued and this effect is stronger in top universities in the U.S. which indicates the impact of selectivity. However, Gurmu et al. (2010) did not estimate a significant contribution for PhD students with temporary visa status.

Another study conducted by Stuen et al. (2012) examines the productivity issue from the perspective of scientific production. By using panel data of publications made by 23 science and engineering departments of 100 top American universities in the period of 1973-1998, Stuen et al. (2012) showed that foreign doctoral students made a positive contribution to publications and citations as well as their American counterparts. Although marginal impact of foreign students seems larger than natives in two-stage IV estimations, Stuen et al. (2012) could not reveal this higher contribution consistently through all specifications. On the other hand, Gaulé and Piacentini (2013) provided evidence that performance of some foreign students can outweigh their native counterparts at least in the context of Chinese students. By using the data collected on 16,000 PhD graduates in 161 American chemistry departments, Gaulé and Piacentini (2013) showed that Chinese students are $22 \%$ to $44 \%$ more productive than their counterparts including average American graduate students based on number of publications and citations.

Those studies listed above show that immigrant post-graduate students make significant positive contributions to their host countries in terms of scientific productivity and even in some cases, they perform better than their native 
counterparts. These positive impacts can be sustained if international PhD students continue to stay in their host countries after completing their studies. U.S. example shows that when high retention among international PhDs can be attained (see Finn, 2014), a host country engages both direct benefits through their innovative or scientific production and indirect benefits through positive spill overs created in specialized research areas and the provision of additional skills such as management and entrepreneurship (Kerr, 2013; Hunt \& Gauthier-Loiselle, 2010; Kerr \& Lincoln, 2010).

\section{Consumption}

International student flows positively affect the demand for goods and services produced in the host country. Increasing demand for consumption goods, accommodation and other services might push production, raise value added in the economy, and contribute the creation of new jobs eventually (Münch \& Hoch, 2013). Münch and Hoch (2013) estimated that average expenditure of an international student for consumption and accommodation was $€ 11,400$ in the Netherlands in $2010 / 11$ which creates an amount of $€ 9,384$ as an annual gross value added per capita and 0.15 annual additional jobs during the study period of international students in the Netherlands.

Münch and Hoch (2013) also showed that these positive impacts due to consumption expenditure are much higher if international students stay in the Netherlands after their graduation and are employed. An international graduate is expected to create an amount of $€ 74,074$ annual gross value added per capita and 0.29 annual additional jobs that can be accounted also as a labour market effect of student mobility (Münch \& Hoch, 2013).

Estimates provided by Münch and Hoch (2013) indicate that student mobility positively contributes to the national economy of a host country through consumption channel but those estimates are limited to bachelor's and master's students so they might be a lower bound of the magnitude of contribution. When credit-mobile students and PhD students are included into those analyses, the magnitude of the contribution is expected to be much higher.

\section{Fiscal balance}

As mentioned earlier, incoming students might create a fiscal burden on the host country's economy due to the costs related to provision of study places and financial support provided. EU students are subject to the same amount of fees paid by Dutch students in the Netherlands and able to get financial support in the form of grants, travel cards, and loan reimbursements (Centraal Planbureau, 2012). Although nonEU students are supposed to bear their own costs during their studies (Centraal Planbureau, 2012), they might benefit from scholarships provided by higher education institutions or Dutch government as explained previously. 
Taking these cost items into account, incoming students can still contribute to fiscal balances of the host country through fees and taxes they pay out of their consumption. Münch and Hoch (2013) estimated that international students create an amount of $€ 2,522$ annual positive impact on Dutch state revenues during their studies while this amount of contribution increases to $€ 19,389$ when international graduates continue to stay in the Netherlands. However, Münch and Hoch (2013) also emphasized a longer time period than the duration of study is needed to cover the full costs of provision of study place mainly borne by the state so retention rate is important in this discussion. According to the estimates of Münch and Hoch (2013), 9,7 and 6,5 years of employment is needed under $20 \%$ and $30 \%$ retention rates, respectively, in order to cover the full cost of study place.

In the report of Centraal Planbureau (2012), the same point is also highlighted. By taking many dimensions of student mobility such as duration of study, size of student inflows and outflows, cost of each incoming and outgoing student, retention rates of incoming students, tax rates, and social security contributions paid by international graduates, Centraal Planbureau (2012) concluded that student mobility contributes to Dutch finances by an amount of 740 million euros annually compared to a hypothetical situation where there is no incoming and outgoing students. It is argued that non-EU students contribute more than their EU counterparts since it is assumed that non-EU students bear all of their costs themselves and positive impacts are expected as long as number of incoming students are higher than number of outgoing students (Centraal Planbureau, 2012). Centraal Planbureau (2012) argues that especially incoming EU students are costly in the short term but these costs are covered in a longer term when those students stay and are employed in the Netherlands.

In the light of these findings, it could be concluded that student mobility positively contributes to fiscal balances of a host country in medium or long term even if it is not so in the short term. In this discussion, the retention rate of incoming students as well as the return rate of outgoing students become important to fully evaluate the long term impacts. Another point is whether non-EU students bring resources during their studies as assumed by Centraal Planbureau (2012) so to what extent financial support is provided to non-EU students should be considered. In addition, the estimations provided by both Centraal Planbureau (2012) and Münch and Hoch (2013) do not include the impact of exchange and PhD students. Exchange students might also create a positive impact on fiscal balances through their consumption even if their study period is very limited but on the other hand, outgoing native exchange students who receive scholarships from the government under Erasmus scheme might have a depressing effect. Furthermore, PhD students are already high skilled migrants so they have higher income and pay more taxes as well as social security contributions so they are most likely to contribute fiscal balances of the host country in a positive way. 